\title{
Teaching Reform of Electronic Curriculum in Vocational Colleges Based on Competition
}

\author{
Honghui $\mathrm{Mu}^{1 *}$, Lei Song \\ Changchun Sci-Tech University, Changchun 13000, China \\ ${ }^{1}$ muhonghui@foxmail.com, ${ }^{293353777 @ q q . c o m ~}$
}

\begin{abstract}
Combined with the practice teaching reform of electronics course and taking electronic contest as the carrier, this paper discusses the practice teaching reform of electronic courses are discussed. Based on managerial guiding ideology, this paper proposes to strengthen practice teaching content reform, and built relatively independent practice teaching system construction of electronic engineering. Apart from putting forward problems of traditional practice teaching mode, this paper also discusses the role of electronic competition in teaching reform, introduces practice teaching reform and innovation. Practice has proved that students' creative quality and comprehensive ability are comprehensively improved.
\end{abstract}

Keywords-Electronic design competition; Practice teaching; Reform; Innovate

\section{INTRODUCTION}

At present, the electronic competition for higher vocational colleges mainly include the national college students electronic design competition and the national vocational college skills competition (electronic product design and production) [1]. The purpose of such competitions is to promote curriculum construction, and pay attention to the cultivation of students' innovative ability, cooperative spirit and solve problems ability. It encourage students carry out extracurricular science and technology activities for college students, and create conditions for outstanding talents to stand out.

With the scale of the electronic design competition is expanding, its effect and significance have been given attention widely, the competitive results can reflect the teaching level of the school, the teaching level of engineering practice disciplines especially. The electronic design competition has aroused the attention of leaders and teachers at all levels in the school. In order to improve students' innovative quality comprehensively, the universities have improved the level of practical teaching, and increased the quality of instruments and equipment. Therefore, the electronic design competition has played a positive role in promoting the reform of school practice teaching.

\section{The Problems of Traditional Practice Teaching MODE}

In the electronic competition, the problems exposed by students fully reflect the deficiency of traditional practice teaching mode.

\section{A. Knowledge is narrow and comprehensive ability is weak}

The design of the construction project proposed scheme that students select is unreasonable, and it is insufficient on scheme comparison and demonstration, students usually apply the reference circuit mechanically and unused the advanced and simple circuit. In addition, the ability of comprehensive application of knowledge analysis is not strong. The main reason is that the basic knowledge, basic theory and basic skills which students master are not strong. In addition, materials and extracurricular books they reading are not enough, and not enough basic skills training.

\section{B. The data access ability is not strong.}

After the topic is chose, the competitor cannot find the relevant information as soon as possible. Most of the students are looking for teaching book and teaching reference book, this behavior reflect the practice teaching deviate from the engineering practice.

\section{The experimental skills are insufficient}

During the competition, some students cannot design the experimental data form properly, they cannot analyze, summarize, conclude and solve problems correctly through experimental data. In the installation and weld process, the operation is non-standard, and the ability of circuit layout, circuit debugging, trouble shooting and trouble removal are weak. This phenomenon is caused by the implementation of practical courses phenomenon that more replication experiments but less design experiments and comprehensive experiments in the study period [2], the students design ability and comprehensive ability have not been developed and improved. 


\section{The computer knowledge applying ability is limited}

In the competition, many subjects must use a single chip microcomputer to complete the design requirements, so they need master the assembly language and $\mathrm{C}$ programming language. Some of the participants failed to achieve good results due to insufficient programming and application ability.

\section{THE ROLE OF ELECTRONIC COMPETITION IN ELECTRONIC INFORMATION TEACHING REFORM.}

The electronic competition plays a very important role in education, and it is also one of the competitions in the labor department. The main purpose of this competition is to develop the ability of innovation and collaboration for students, the students complete the electronic design according to the requirements and solve practical problems. Through the effective development of the competition can improve the comprehensive ability of each student [3].

\section{A. The combination of theory and practice promotes the perfection of teaching system}

With the continuous improvement of the national labor department in the field of electronic competition, it is necessary to make targeted adjustments in the training of specialized talents at the present stage. First of all, the courses should be sorted out to avoid repetition of teaching content. At the same time, in order to broaden student's horizon, let them understand the development of electronic information technology in today's society, the school need to organize related academic lectures regular, and impart the new knowledge to the students by professional teacher or engineer. Secondly, practice and theory should be combined organically, while carrying out theoretical teaching, we should actively carry out practice and training at the same time, let every student can participate in the experiment, realize the pleasure of this course, and cultivate their interest. At the same time, it is necessary to set up another electronic design experiment in the experimental course, then schedule time for students to participate in the process to improve their hands-on skills.

\section{B. It is beneficial for the practical teaching system}

The introduction of electronic competition can promote the improvement of students' ability in practice and innovation. In order to promote students' ability of electronic competition, the school needs to reform the teaching system of practical training courses to training students innovation from understanding to training, which can promote students set up perfect knowledge network in the process of training, and understand the contents of the experiment, improve the innovative ability of students through training.

\section{It helps to promote the development of theoretical teaching}

A journey of a thousand miles begins with a single step, and any work carried out needs to be done well. This is especially true for electronic competitions, which basic knowledge is important if you want to get good grades. Therefore, theoretical teaching are appreciate in the course of education for students. In the recent years of electronic competition, the content of the competition is mainly the investigation of basic theory knowledge, which is related to the textbooks used by various vocational schools at present, it is also based on the basic knowledge for the design topic in the textbook, through the application of this knowledge to complete the design of electronic technology, digital electronic technology, analog electronic technology, electronic CAD technology and single-chip microcomputer are covered. One of the most important aspects of the design work is that students have a very deep knowledge of basic knowledge.

\section{ELECTRONIC COMPETITION PROMOTES PRACTICAL TEACHING REFORM AND INNOVATION}

Take the electronic design competition as an opportunity, the problems exposed in the competition, such as curriculum setting, practical content and comprehensive ability are need solve as an urgent problem though reform and discussion the teaching content, teaching mode of electronic practical courses system. The electronic design competition has put forward higher requirements for colleges and universities to pay more attention to training students' practical ability and innovative design ability in teaching reform.

\section{A. Strengthen theory and practice teaching content reform}

The relatively independent teaching system for electronic majors are constructed, we should change the traditional educational concept from teacher centered to student oriented and teacher - oriented education mode. From the experimental verification of a single theoretical course as the center transformed into hierarchical and comprehensive experimental course system. The main measures are as follows Firstly, pay attention to update the content of the textbook in the process of theoretical teaching, and introduce new theories and technologies to students constantly. Secondly, encourage students to read the relevant electronic publications, then use reading notes as part of their homework or exams. Thirdly, use heuristic teaching to motivate students' enthusiasm and participation, and activate students' innovative thinking to change passive learning becomes active learning.

\section{B. Reform experimental teaching methods}

The traditional experimental teaching is that the teacher's explanation and the students do it, the experimental equipment is also mostly experimental box and experimental development board, most of the circuits have been set up. Students only need to make simple connection according to the experimental instruction book, and the teaching methods are single and rigid. In the experiment teaching, the computer and EDA technology are introduced, and the traditional experiment teaching and Proteus simulation are combined. Let students use Protel simulation to design circuits, simulate and explore rules firstly, then build circuits themselves. This 
experimental form can promote student's independent thinking ability and improve their practical ability.

\section{Reform curriculum design content}

Curriculum design is a very important part of practice teaching, which is usually the same subject of the whole class, the unified grading standard and uniform grading standards in the past, this conditions lead to the whole class have same conclusion, some students borrow indiscriminately from other people's experience, which did not achieve the purpose of the course design. In order to change this disadvantages, the project teaching method in the course design are applied. The whole class are divide into several groups (each group is controlled by three or four people) and have a different topic, which method can prompts each student to participate in the design. The topics students select is taught in accordance with their aptitude, which is not only suitable for most students' ability, but also has the difficult and challenging problems set by excellent students. In the design process of the project, students should play the main role from data inquiry, program demonstration, software simulation, system debugging and final submission report, the whole process is completed by students themselves, and the teacher is only a guiding role. The relationship between the teacher and student as shown in figure $1[4]$.

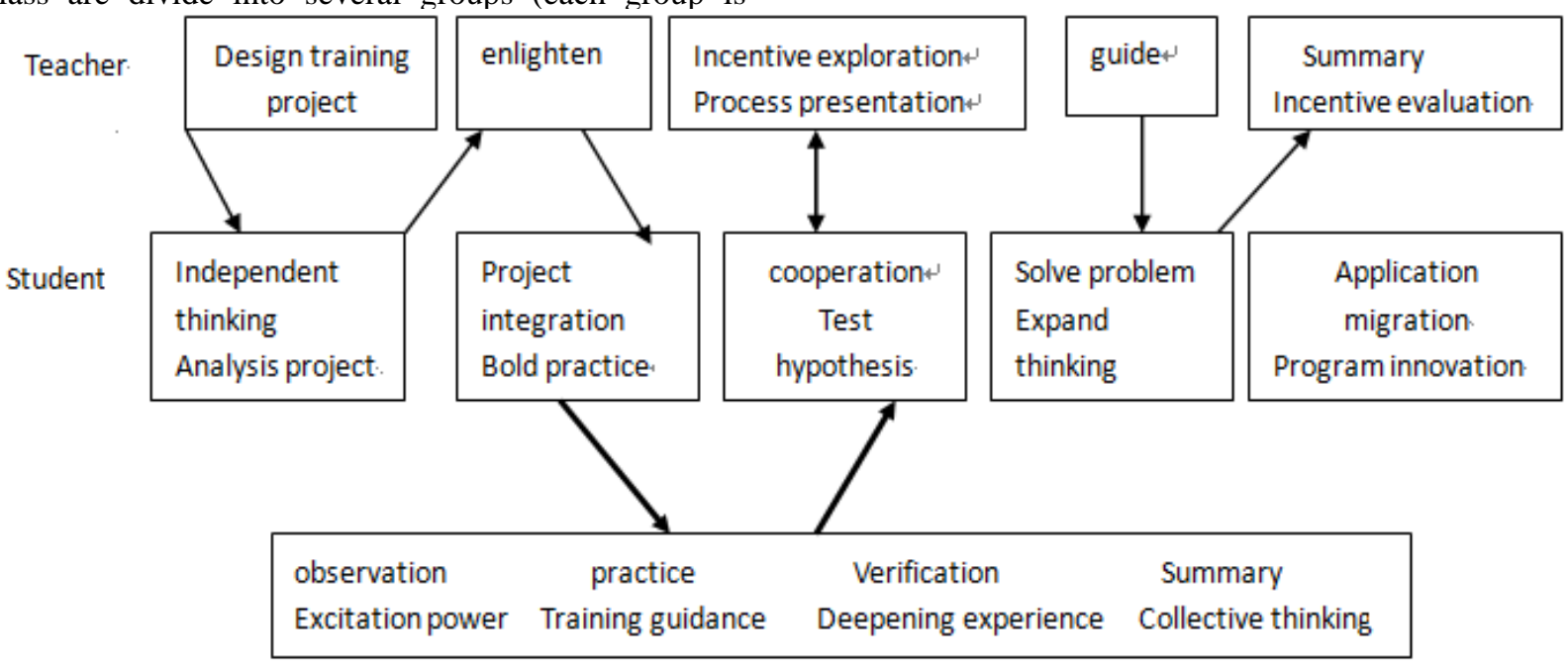

Fig. 1. The processing of the project training

\section{To strengthen laboratory reform and innovation}

The open experimental teaching mode improves the efficiency of experimental teaching and cultivates students' independent working ability effectively, which is conducive to the development of students' personalities and strengthen students' practical ability and innovation ability [5]. In order to play a role of open laboratory, it is necessary to develop scientific and effective laboratory management methods to ensure the orderly progress of open laboratories. The opening of the laboratory should be hierarchical and open different levels laboratory according to the needs of students at different levels. Strengthen guidance to students, and let students know clearly what to do and how to do through open laboratory.
Revising the teaching plan and establish a new teaching system based on the open laboratory, and make clear the role of open laboratory from teaching plan.

\section{E. Project-based teaching is the focus}

It is mainly based on project teaching and group cooperative learning, combined with various methods to improve students' technical and professional ability. Teaching method reform according to training objectives and curriculum characteristics are implement, the practice concept which base on CDIO engineering as shown in figure 2 [6]. The classroom teaching and problem teaching are combined to change the state of accept knowledge passively in the course of theory teaching. 


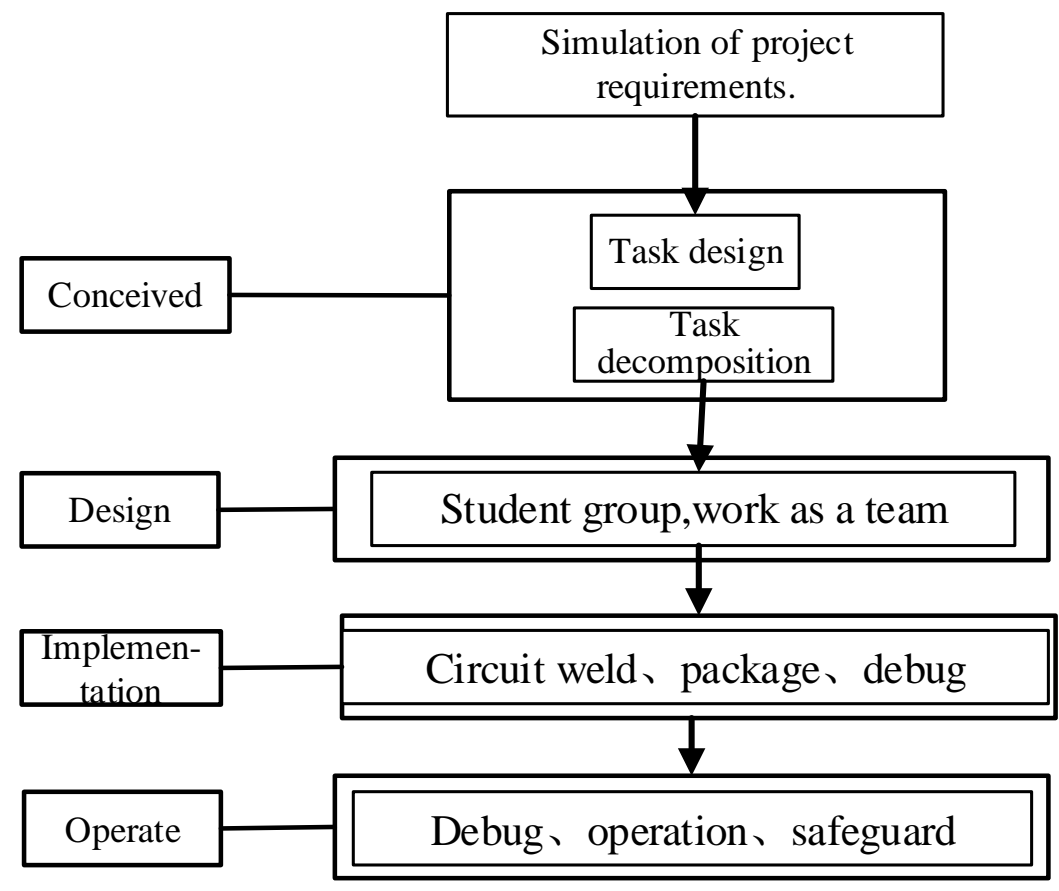

Fig. 2. The flow of simulate project execution

\section{CONCLUSION}

Practical teaching is a very important part of the whole teaching, it is important link to put the theoretical knowledge into practical ability, it is also important approach to cultivate creative thinking habit and innovative personality. Practical teaching play an important role in student quality, innovation ability and practice ability. The national undergraduate electronic design competition give direction for electronic practical teaching reform, we should take this opportunity to promote the electronic experimental course reform, make practical courses keep up with the pace of the times development. Students have ability to design and explore capacity after learning the professional course of electronic. Through the continuous exploration and practice in recent years, the practical teaching reform of electronic specialty courses has achieved certain achievements, and it is applied in students majoring in the electronic information science and technology, the practice proves that these reform measures have achieved better teaching effect.

\section{ACKNOWLEDGMENT}

This work was 2017 professional education and adult education reform research subject of Education department subject in Jilin province; Project approval no.:2017ZCY307.

\section{REFERENCES}

[1] Liang Q W, Zhou Q X. Electronics Design Contest and Experiment Teaching Study [J]. Journal of Changchun Normal University, 2008.

[2] Wang W, Wang Y. The teaching reform of integrated curriculum in vocational colleges based on typical tasks [J]. Journal of Jiamusi Vocational Institute, 2017

[3] LI Cui, LUO Xiaoni, SONG Chengxiang. The Role of Electronic Contest in Vbcational College Electronic Specialty Teaching Reform [J]. China Education Innovation Herald, 2015.

[4] MU Honghui, WANG Haiyan. Design and Practice of Integrated Engineering Training Project Based on CDIO mode. International Society for Seed Science 2017, 2017.

[5] Chen J Y, University N V. The Reform of Physical Education Curriculum in the Vocational College Based on the Ideal of University [J]. Journal of Nantong Vocational College, 2014.

[6] Wang T. A Discussion on Teaching Reform of Project-based Digital Electronic Technology Curriculum in Higher Vocational Colleges [J]. Journal of Wenshan University, 2012. 